\title{
Chamois and the Karst of Herzegovina
}

\author{
Preston Miracle ${ }^{a}$ and Derek Sturdy ${ }^{b}$
}

(Received 14 December 1989, revised manuscript accepted 25 May 1990)

The presence of chamois in faunal assemblages from a low altitude, Epipaleolithic rockshelter in Herzegovina, Yugoslavia, has altered our conception of the ecology of chamois and of the history of the Herzegovinan karst during the last 15,000 years. We infer that on the low-altitude plateaus of southern Herzegovina, the chamois appear to have exploited a Late Glacial equivalent of "angry karst", a "degraded" karst landscape formed primarily by solutional processes on harder limestones. This would imply that one cannot assume a stable alpine ecology for chamois. The possibility of a nonalpine adaptation of chamois has led us also to reconsider the history of karst landscapes in Herzegovina during the last 15,000 years. We conclude that if the Holocene degradation of the Herzegovinan karst is viewed in a wider, Late Pleistocene, time window, the exceptional circumstance is not the modern landscape of "angry karst". but the short period in the Early Holocene when the landscape was more heavily vegetated.

Keywords: HERZEGOVINA, CHAMOIS, KARST, QUATERNARY.

\section{Introduction}

Studies of the ecology and behaviour of the modern chamois (Rupicapra rupicapra) have stressed its adaptation to alpine environments (Couturier, 1938: 271; Corbet, 1966: 178; Kurtén, 1968: 175). If the chamois can be accepted as basically an alpine animal, then it would be possible to plot its past distribution as a simple function of altitude relative to snow lines. Thus, zooarchaeologists have commonly shifted the chamois down the mountain slopes during glacial or cold periods (Couturier, 1938: 280; Bouchud, 1975: 139; Bonifay, 1982). Because we held this common assumption, we were surprised to find abundant chamois in the ungulate fauna from the rockshelter of Badanj (southern BosniaHerzegovina, Figures 1 and 2), since the site is situated at an altitude of about $100 \mathrm{~m}$ and is surrounded by a karstic plateau. This discovery has led us to question whether chamois ecology has been as stable as assumed and to examine how its ecology has, in fact changed.

The site of Badanj was excavated from 1986-7 as part of a joint American--Yugoslavian research project between the University of Michigan Museum of Anthropology and the Zemaljski Muzej, Sarajevo, "Paleolithic-Mesolithic Occupation of the AdriaticMediterrancan Zone of Bosnia-Herzegovina"'. The 25 excavated levels contained rich assemblages of Epipaleolithic artifacts, animal bones, and habitation features. The lowest

${ }^{4}$ Museum of Anthropology, University of Michigan, Ann Arbor, MI 48109, U.S.A.

${ }^{h}$ Institute of Prehistoric Science and Archaeology, University of Liverpool, P.O. Box 147, Liverpool L69 3BX, U.K. 


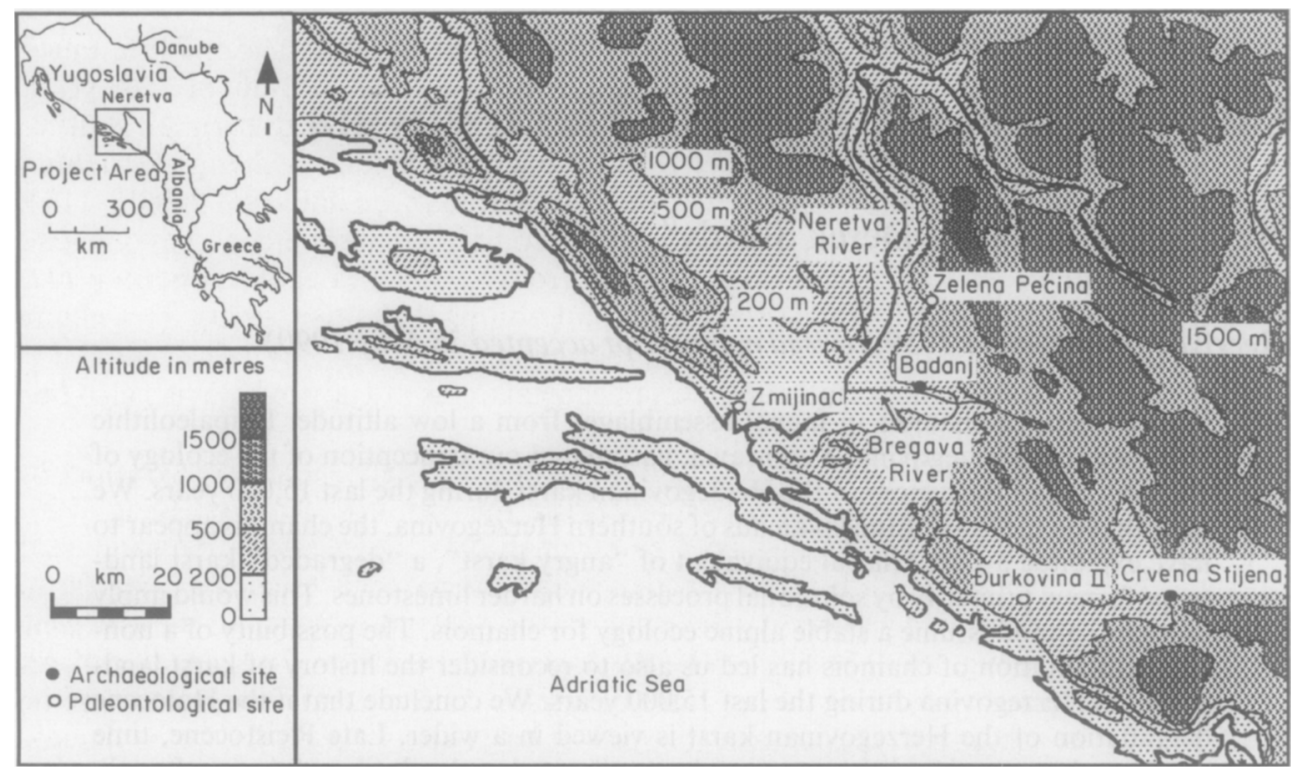

Figure 1. Topographic map of southeastern Herzegovina with major archaeologi$\mathrm{cal}$ and paleontological sites. The inset locates the project area within the AdriaticDinaric region of Yugoslavia.
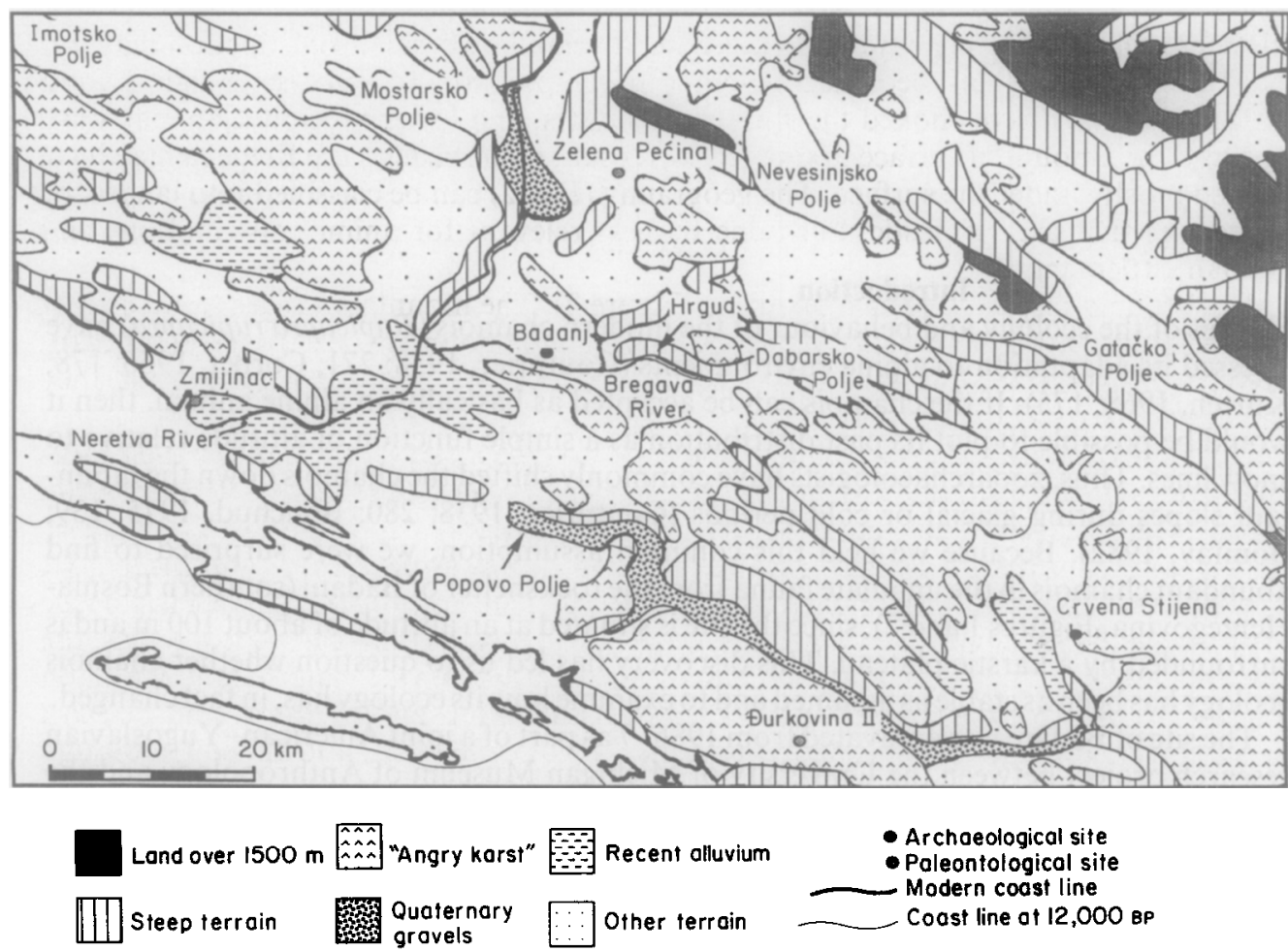

Figure 2. The geography of southeastern Herzegovina and major archaeological and paleontological sites (project area same as Figure 1). 
of the excavated levels, level 13 , has been dated at $13,200 \pm 150 \mathrm{BP}(\mathrm{OxA}-2196$, uncalibrated AMS radiocarbon date on burnt bone calculated using a half-life of 5568 years). The lithic assemblages are typologically similar to the final Epigravettian in the southern Adriatic area of Italy (Whallon, 1989). The assemblage composition changes roughly in the middle of the stratigraphic sequence (level 6). Level 6 has been dated at $12,380 \pm 110 \mathrm{BP}$ (OxA-2197). Assemblages from levels below level 6 contain greater percentages of backed bladelets and microgravettes, while assemblages from level 6 and above contain greater percentages of "thumbnail" flake scrapers and microliths (Whallon, 1989). This change closely parallels the transition between the earlier and later phases of the final Epigravettian in the southern Adriatic and Ionian coastal areas of Italy, which has also been dated at about 12,000 BP (Bartolomei et al., 1979).

The possibility of a non-alpine adaptation of the chamois then led us to reconsider the history of karst landscapes in Herzegovina during the last 15,000 years. Beug (1967) argued forcefully for a loss of soil and tree cover during the last few thousand years owing to human activity. While there is evidence that the modern "degraded" landscape developed during the Mid Holocene, the prior status of karst areas has not been clear. Pollen diagrams (Beug, 1962; Brande, 1973) do not stretch back into the Late Glacial, and geomorphic techniques for calculating rates of karst solution pedogenesis, etc., are not amenable to the accurate description of the state of karst areas during the Late Glacial.

\section{Present Landscape and Landuse of Southern Herzegovina}

Herzegovina has been recognized as classic karst since the late 19th century (Herak, 1972) and is fluviokarstic, or merokarstic in Cvijićs (1960) terminology. The river valleys are important in the landforms, in contrast to parts of Montenegro to the south where almost all the drainage is purely karstic. In the Late Glacial, however, this distinction may not have been so important, because, compared to the present, increased scree falling from valley walls may have choked the steep river valleys, and lower precipitation may have reduced the amount of surface drainage. As a result, rivers such as the Bregava may have flowed mostly under the surface. The geography (Fig. 2) can be classified into landscape categories that are simplistic, but none the less relevant for animal distributions and human settlement:

(1) Mountains ("land over $1500 \mathrm{~m}$ " on Figure 2). The mountain ranges trend mainly WNW-ESE, with inland peaks rising to $2500 \mathrm{~m}$. The mountains are rugged and carry some tree cover with a substantial amount of bare rock. Where slope angles permit, they are heavily grazed by sheep and goats.

(2) Poljes (karstic valleys). Poljes divide into two categories on the basis of their morphologies and depositional histories. The Neogene poljes are relatively wide, contain mostly older deposits, and commonly are the sites of lakes or dry-lake beds. Their gently rolling landscape has made them suitable for some arable farming, cattle and sheep/goat grazing. The major Neogene poljes are identified by name on Figure 2 . The Pleistocene poljes are either comparatively small, or long and narrow. In the long narrow poljes, the deposits are mainly gravels, and the sides are frequently steep ("Quaternary gravels" on Figure 2). In the more irregular poljes, soil accumulation allows arable and orchard farming. In both types of polje, periodic floods made farming risky and difficult, although recent flood control systems have alleviated much of the problem (Rodić, 1986: 213).

(3) "Angry karst". In the "angry karst" the amount of soil produced is comparatively small and fissuring in the rock makes it easy for soil to be washed below the surface. As a result, soil cover today is characteristically minimal and restricted to pockets between sharp, bare, and heavily dissected limestone with frequent spitzkarren ranging in height from $500-2000 \mathrm{~mm}$, and there is a clean dividing line between rock and soil. "Angry karst" is restricted to the etched surface of massive finegrained limestones and can occur 


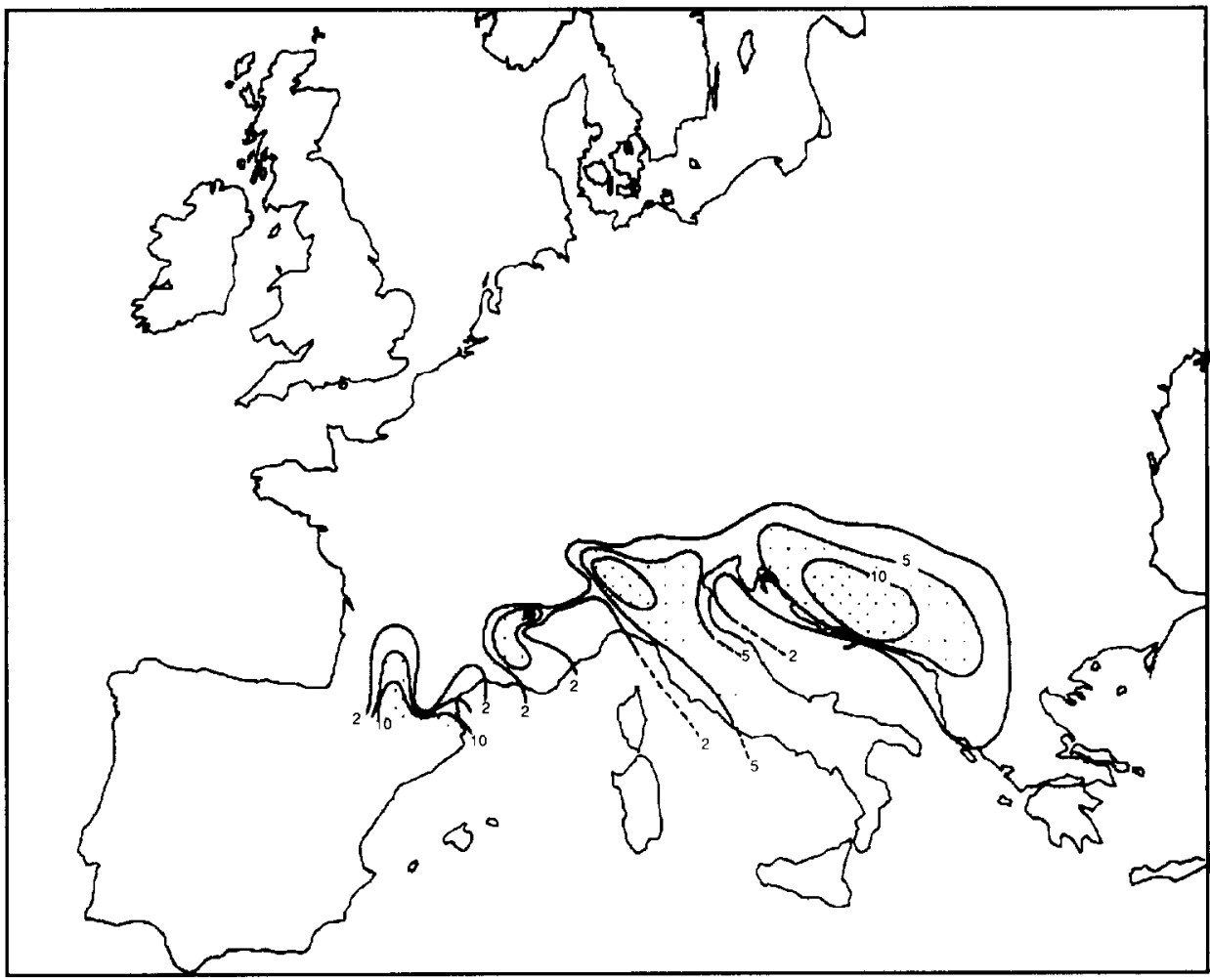

Figure 3. Isopoll map of Abies at 7500 BP. From Huntley \& Birks (1983: figure 5.7) reproduced with kind permission.

on a variety of slope angles, from completely flat to moderately steep, and at altitudes from close to sea level to over $1000 \mathrm{~m}$. The associated vegetation today is often dominated by Paliurus spinachristi (Christ's thorn) and other plants indicative of heavy grazing pressure. Negotiating "angry karst" on foot is often difficult for large ungulates owing to the sharpness of the bare rock and the extreme unevenness of the terrain. A slip on the sharp, dissected limestone can result in serious injury.

(4) Steep terrain. Steep terrain is defined by local slope angles and the absence of karstic features characteristic of "angry karst" for altitudes under $1500 \mathrm{~m}$.

(5) Moderate limestone terrain ("other terrain" on Figure 2). The moderate terrain is formed on softer, chalky limestones that tend to weather relatively rapidly and produce thicker subsoils and soils. This land surface is relatively easily traversed by animals and people.

\section{Vegetational History in Southern Herzegovina}

We use pollen maps presented in Huntley \& Birks (1983) to reconstruct pollen diagrams for southern Herzegovina. We calculated our pollen data by extrapolating from the "isopoll" lines of pollen percentage in Huntley \& Birks' maps (1983) (Figure 3). These "raw data" were listed, by taxon, at 500 -year intervals, as discrete values or ranges in values (Table 1). Missing values for particular taxa and time intervals were listed as "no data". The "raw data" were then crudely smoothed by interpolating between known data points (for missing data) and calculating the average value (for ranges of values) to create a continuous record of data at 500 -year intervals. 
Table 1. Example of pollen data smoothing (data extracted from Huntley \& Birks, 1983)

\begin{tabular}{rcc}
\hline Date BP & $\begin{array}{c}\text { "Raw data" extracted from } \\
\text { Huntley } \begin{array}{c}\text { \& Birks (1983) } \\
\text { Abies }\end{array}\end{array}$ & $\begin{array}{c}\text { Adjusted data } \\
\text { Abies }\end{array}$ \\
\hline 0 & 2 & 2 \\
500 & N.D. & $1 \cdot 5$ \\
1000 & $<2$ & 1 \\
1500 & N.D. & $1 \cdot 5$ \\
2000 & 2 & 2 \\
2500 & N.D. & $1 \cdot 5$ \\
3000 & $<2$ & 1 \\
3500 & N.D. & 1 \\
4000 & $<2$ & 1 \\
4500 & N.D. & 1 \\
5000 & $<2$ & 1 \\
5500 & $2-5$ & $3 \cdot 5$ \\
6000 & 2 & 2 \\
6500 & N.D. & $2 \cdot 75$ \\
7000 & $2-5$ & $3 \cdot 5$ \\
7500 & $5-10$ & $7 \cdot 5$ \\
8000 & 0 & 0 \\
8500 & N.D. & 0 \\
9000 & 0 & 0 \\
9500 & N.D. & 0 \\
10,000 & 0 & 0 \\
10,500 & N.D. & 0 \\
11,000 & 0 & 0 \\
11,500 & N.D. & 0 \\
12,000 & 0 & 0 \\
12,500 & N.D. & 0 \\
13,000 & 0 & 0 \\
\hline
\end{tabular}

N.D. $=$ No data.

In the case of southern Herzegovina, Huntley \& Birks' maps are a good basis for extending pollen sequences into the Late Glacial periods. Huntley \& Birks' diagrams suggest likely ways in which vegetation could vary with altitude and distance from the coast. Their maps are thereby useful for inferring the probable pollen distribution in the absence of direct evidence. One danger of such extrapolations, of course, is that the neat vegetational change at 10,000 BP (Figure 4) is not a reflection of Herzegovinan pollen data so much as an extrapolation from ideas of the Late Glacial to post-Glacial change elsewhere in Europe. The arid Late Glacial environment suggested by the work of Bottema (1974) in Epirus, $300 \mathrm{~km}$ to the south, however, makes Huntley \& Birks' reconstructions plausible.

We use the results of our reconstructed diagrams (Figure 4) to show the variation in tree and plant species interpretable in terms of environmental change. We have not attempted to reconstruct complex sequences of community succession. On the basis of the dramatic expansion of woodlands shown in the pollen data at 10,000 BP, we place the Late Glacial/ post-Glacial boundary in southern Herzegovina at about $10,000 \mathrm{BP}$. We draw attention to two particular points. First, trees (Juniperus, Phillyrea, Ostrya, Quercus ilex) characteristic of the modern maquis community were present and slowly increase in abundance from the early post-Glacial onwards. They do not increase in phase, but show a staggered pattern over time. The maquis community is often regarded as the end product of oak 

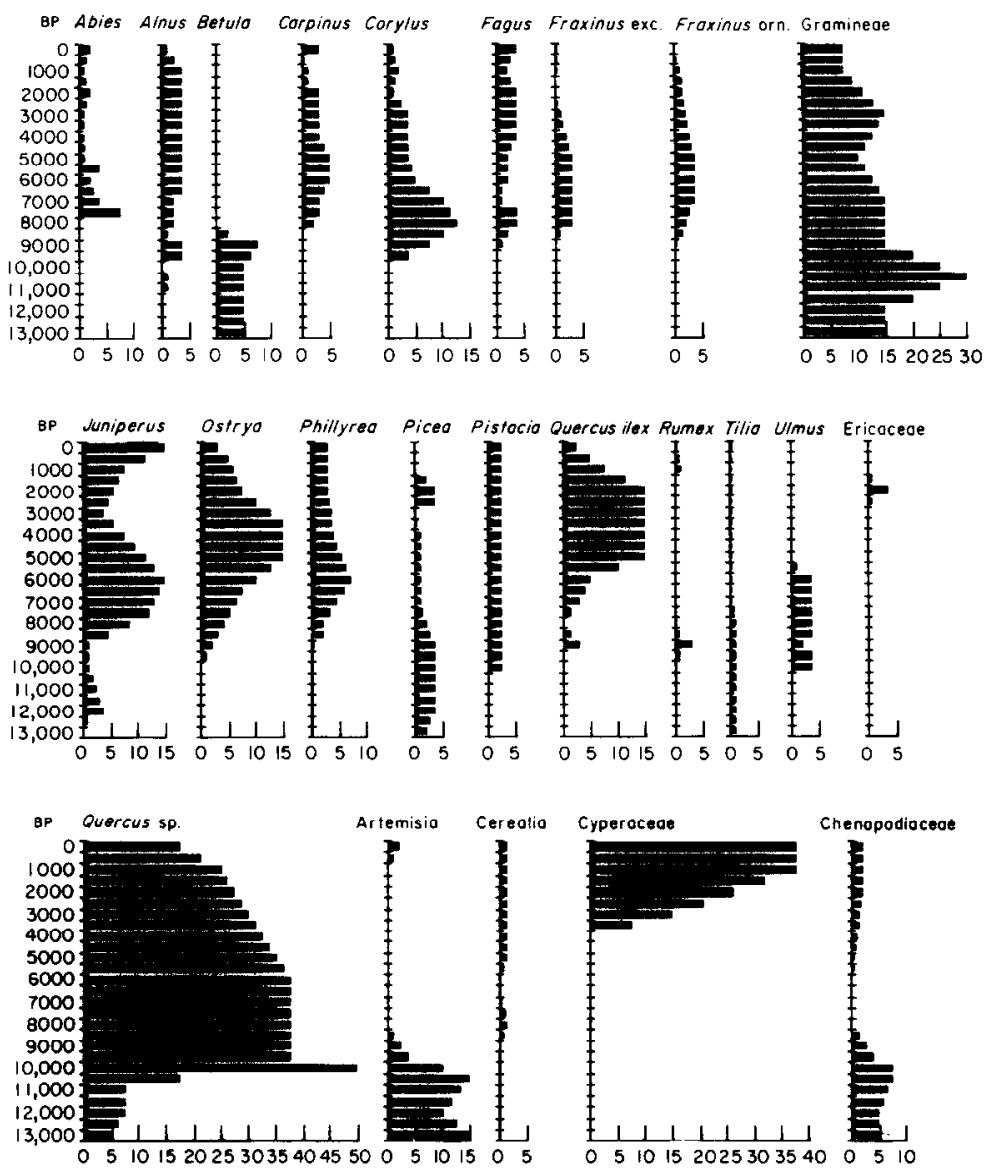

Figure 4. Pollen diagrams for southeastern Herzegovina based on Huntley \& Birks (1983). Pollen percentages are plotted by 500 year intervals.

forest degradation under herd grazing and fuel collecting by humans (van Andel \& Sutton, 1987: 8). The occurrence of maquis-associated trees right at the start of the post-Glacial suggests that grazing pressure, to some degree, has been a constant feature of this area. Second, the parkland/woodland species are not easy to interpret in terms of conventional zonation. However, the Corylus curve is important because hazel is very characteristic of modern Bosnian parkland communities that occur at higher altitudes with higher rainfall farther inland from Badanj. Hazel requires considerable soil depth for its development. The evidence of ash (Fraxinus) and deciduous oaks reinforces this point, although the interpretations are more equivocal. The susceptibility of elm (Ulmus) to disease makes us unwilling to assign any significance to its decline in abundance in terms of either climatic changes or human practices. Following Beug $(1967: 278)$ we are wary of over-interpreting the Fagus, Abies and Picea curves. Similarly, we have deliberately excluded the pine (Pinus) from this diagram (Fig. 4) since we do not know how to reliably interpret pine pollen curves in a study of this kind. The frequency of Cyperaceae rises from $3500 \mathrm{BP}$ onwards in the lower Neretva Valley (Brande, 1973). This increase is probably related to the tectonic sinking of the Dalmatian coast and the consequent increase in salt marshes near to the location of the pollen cores. 
Thus, from this diagram (Figure 4) we can make the following general conclusions. The Late Glacial Herzegovinan lowlands carried steppe or lightly wooded steppe communities. The steppic flora was replaced in the Early post-Glacial by parkland, deciduous woodland and in lesser quantities species that subsequently dominated the maquis communities of modern times. The bulge in Corylus abundance in the Early Holocene also indicates an increase in soil cover. The subsequent increase in frequency of maquisassociated plants during the Mid Holocene suggests a decrease in soil cover. Beug's (1975: 77) view of this change during the Holocene was of degradation caused by forest clearance and farming. However, if one widens the frame of reference to include the Late Glacial as well as the post-Glacial, a different developmental sequence emerges. The basis of our reanalysis comes from the Badanj faunal assemblages.

\section{The Badanj Fauna}

The abundance of ungulate species is presented in Table 2 (oldest levels at the bottom). We limit our discussion to the levels excavated in the front of the shelter in which the stratigraphic succession of levels can be followed the most clearly. The ungulates used in this analysis are: chamois ( $R$. rupicapra), goat (most likely Capra ibex), red deer (Cervus elaphus), roe deer (Capreolus capreolus), pig (Sus scrofa), large bovids (Bos or Bison), and ass (most likely Equus hydruntinus). Species abundance has been measured as number of identified specimens (NISP) and minimum number of individuals (MNI). These measures display similar changes in species abundance over time, suggesting that the broad pattern of changes is neither a product of differential bone fragmentation (causing inflated NISPs) nor small sample biases (affecting MNIs).

Taphonomic indicators suggest that the Badanj ungulate fauna accumulated as a result of human subsistence practices. Carnivore remains are very rare in the assemblage, and evidence of carnivore modification is rare. The frequencies of body parts of the most abundant ungulate taxa (red deer, chamois/ibex and roe deer) suggest that carcasses and carcass parts were not transported long distances (over several kilometers) to the site (Tables 3-6). While the frequencies of body parts of pig, Bos/Bison and equids (Tables 7-9) are congruent with this interpretation, we consider these sample sizes to be too small to warrant any conclusions based on these data. In each case, low utility elements such as feet and heads are much more abundant than higher utility elements such as upper limbs and trunk elements (the inclusion of fragments identified to body part but not genus does not change this pattern). On the basis of nutritional utility and logistical costs, one would expect these elements to be abandoned or processed for marrow at kill or butchery sites (Binford, 1978: 81-3). Thus, we consider it highly unlikely that the Epipaleolithic hunters would have carried entire chamois carcasses long distances to butcher them at Badanj, or carried only the heads and feet to the site. One can conclude, at the very least, that animals present in the Badanj assemblages were present in the local region at some season during the year.

In Figure 5(a) - (c) we have converted NISP values into percents and graphed them by excavation level (oldest at the bottom). On the basis of the expansion of woodlands shown in the pollen data at 10,000 BP (Figure 4), we place the Late Glacial/post-Glacial boundary in southern Herzegovina at about $10,000 \mathrm{BP}$. We tentatively place the Late Glacial/postGlacial boundary in the Badanj sequence between levels 3 and $2 \mathrm{AB}$ on Figure 5(a)-(c). Our interpretation is based on changes in the abundance of roe deer [Figure 5(c)]. Roe deer is virtually absent [Figure 5(c)] in assemblages from levels 17-8 with radiocarbon dates between 13,200 and 12,380. The pollen data from before 12,000 BP (Figure 4) indicate only a little forest in predominantly steppic communities. The correspondence between a lack of forests and a lack of roe deer is probably not coincidental in light of the roe deer's preference for forest habitats (Kurtén, 1968: 167). Dating to sometime after 12,000 BP, roe 


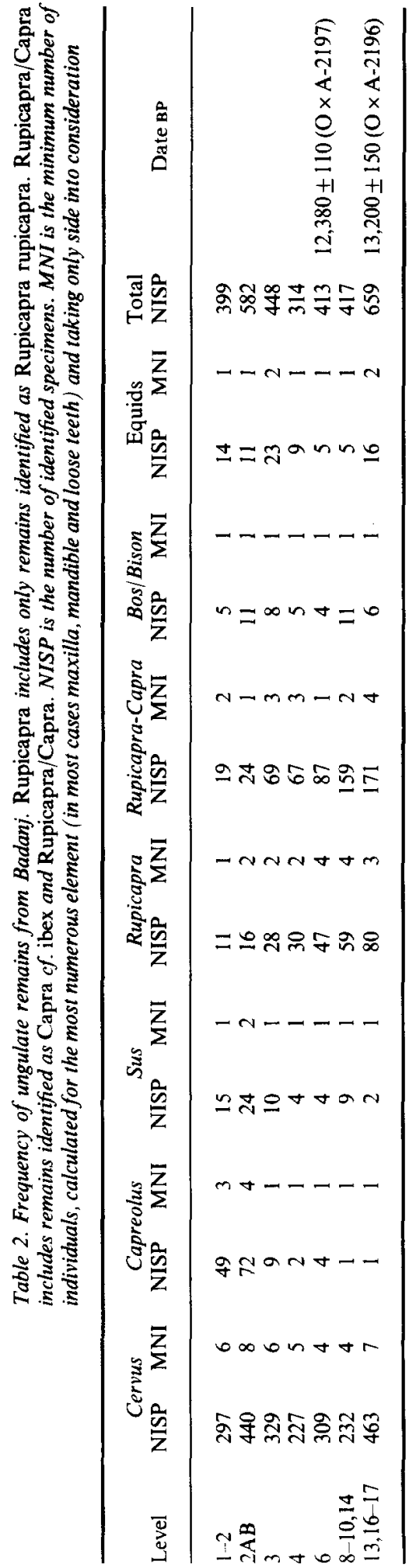


Table 3. Body part frequency of Cervus remains from Badanj. Petrous is the petrous portion of the temporal bone. Maxilla and mandible include loose upper and lower teeth respectively. Small tarsal includes the lateral malleolus (distal fibula) and tarsals exclusive of the navicular-cuboid

\begin{tabular}{|c|c|c|c|c|c|c|c|}
\hline \multirow[b]{2}{*}{ Body part } & \multicolumn{7}{|c|}{ Excavation levels } \\
\hline & $\begin{array}{c}1-2 \\
\text { MNI }\end{array}$ & $\begin{array}{l}2 \mathrm{AB} \\
\mathrm{MNI}\end{array}$ & $\stackrel{3}{\mathrm{MNI}}$ & $\stackrel{4}{\mathrm{MNI}}$ & $\stackrel{6}{\mathrm{MNI}}$ & $\begin{array}{c}8-10,14 \\
\text { MNI }\end{array}$ & $\begin{array}{c}13,16-17 \\
\text { MNI }\end{array}$ \\
\hline Antler & 1 & 1 & 1 & 1 & 1 & & 1 \\
\hline Petrous & 1 & 2 & 6 & 2 & 2 & 2 & 4 \\
\hline Maxilla & 2 & 5 & 3 & 1 & 4 & 2 & 4 \\
\hline $\begin{array}{l}\text { Mandible } \\
\text { Atlas }\end{array}$ & 6 & 8 & 4 & 1 & 4 & 2 & 6 \\
\hline Axis & & 1 & & & & & 1 \\
\hline \multicolumn{8}{|l|}{ Cervical vertebra } \\
\hline \multicolumn{8}{|l|}{ Thoracic vertebra } \\
\hline \multicolumn{8}{|l|}{$\begin{array}{l}\text { Lumbar vertebra } \\
\text { Sacrum }\end{array}$} \\
\hline $\begin{array}{l}\text { Sacrum } \\
\text { Innominate }\end{array}$ & & 2 & 1 & 1 & 2 & 2 & 1 \\
\hline \multirow{2}{*}{\multicolumn{8}{|c|}{$\begin{array}{l}\text { Rib } \\
\text { Sternebra }\end{array}$}} \\
\hline & & & & & & & \\
\hline Scapula & 1 & 1 & & & & & 1 \\
\hline Proximal humerus & & & & & & & 1 \\
\hline Distal humerus & 2 & 2 & 3 & 1 & & 1 & 2 \\
\hline Proximal ulna & 2 & 2 & 1 & 1 & 4 & 3 & 2 \\
\hline \multicolumn{8}{|l|}{ Distal ulna } \\
\hline Proximal radius & 2 & 2 & 2 & 1 & 1 & 1 & 4 \\
\hline Distal radius & & 1 & 1 & & & & 1 \\
\hline Carpal & 2 & 4 & 4 & 3 & 2 & 3 & 4 \\
\hline Proximal metacarpal & 3 & 4 & 4 & 5 & 3 & 3 & 3 \\
\hline Distal metacarpal & & 1 & & 1 & 2 & & 2 \\
\hline Proximal femur & 1 & & & 1 & 1 & 1 & 2 \\
\hline Distal femur & 1 & 2 & 1 & & & 2 & 2 \\
\hline Proximal tibia & & & & & & & 1 \\
\hline Distal tibia & 2 & & 1 & & 1 & 3 & 2 \\
\hline Small tarsal & 2 & 2 & 4 & 2 & 3 & 3 & 7 \\
\hline Navicular-cuboid & 1 & 2 & 3 & 3 & 2 & 3 & 4 \\
\hline Astragalus & 3 & 2 & 2 & 2 & 2 & 2 & 3 \\
\hline Calcaneus & 3 & 3 & 2 & 1 & 3 & 4 & 3 \\
\hline Proximal metatarsal & 1 & 4 & 3 & 4 & 3 & 2 & 4 \\
\hline Distal metatarsal & & 1 & 1 & 1 & 2 & & 2 \\
\hline Phalanx 1 & 4 & 4 & 4 & 2 & 4 & 2 & 4 \\
\hline Phalanx 2 & 2 & 2 & 1 & 1 & 2 & 2 & 3 \\
\hline Phalanx 3 & 1 & 1 & 2 & 1 & 3 & 1 & 2 \\
\hline
\end{tabular}

deer increases dramatically in abundance in level $2 \mathrm{AB}$ [Figure 5(c)]. Again, we note a close parallel with vegetational changes based on the pollen data (Figure 4). Although arboreal pollens are slightly more abundant between $12,000 \mathrm{BP}$ and $10,000 \mathrm{BP}$, they dramatically increase in abundance after $10,000 \mathrm{BP}$ with the beginning of the post-Glacial. On the basis of this strong parallel between vegetational changes and roe deer abundance, we date levels 4 and 3 to before 10,000 BP and levels 2AB-1 to after 10,000 BP. Thus, on the basis of radiometric dates and our pollen reconstruction, we divide the sequence into Late Glacial (levels 17-3) and post-Glacial (levels 2AB-1) levels.

The most abundant taxon (red deer) and the most important sources of meat and fat (red deer, Bos/Bison and equids) are relatively constant in frequency throughout the 
Table 4. Body part frequency of Rupicapra remains from Badanj. Data are quantified as NISP. Element categories as in Table 3

\begin{tabular}{|c|c|c|c|c|c|c|c|}
\hline \multirow[b]{2}{*}{ Body part } & \multicolumn{7}{|c|}{ Excavation levels } \\
\hline & $\begin{array}{c}1-2 \\
\text { NISP }\end{array}$ & $\begin{array}{l}2 \mathrm{AB} \\
\text { NISP }\end{array}$ & $\begin{array}{c}3 \\
\text { NISP }\end{array}$ & $\begin{array}{c}4 \\
\text { NISP }\end{array}$ & $\begin{array}{c}6 \\
\text { NISP }\end{array}$ & $\begin{array}{c}8-10,14 \\
\text { NISP }\end{array}$ & $\begin{array}{c}13,16-17 \\
\text { NISP }\end{array}$ \\
\hline $\begin{array}{l}\text { Horn core } \\
\text { Petrous }\end{array}$ & & & & & 1 & 2 & \\
\hline Maxilla & 1 & 4 & 9 & 4 & 8 & 9 & 17 \\
\hline Mandible & 4 & 7 & 7 & 4 & 7 & 27 & 27 \\
\hline \multicolumn{8}{|l|}{ Atlas } \\
\hline \multicolumn{8}{|l|}{ Axis } \\
\hline \multicolumn{8}{|l|}{ Cervical vertebra } \\
\hline \multicolumn{8}{|l|}{ Thoracic vertebra } \\
\hline \multicolumn{8}{|l|}{ Lumbar vertebra } \\
\hline \multicolumn{8}{|l|}{ Sacrum } \\
\hline Innominate & & & & & & 2 & \\
\hline \multicolumn{8}{|l|}{ Rib } \\
\hline \multicolumn{8}{|l|}{ Sternebra } \\
\hline Scapula & & & & & & 1 & \\
\hline \multicolumn{8}{|l|}{ Proximal humerus } \\
\hline \multirow{2}{*}{\multicolumn{8}{|c|}{$\begin{array}{l}\text { Distal humerus } \\
\text { Proximal ulna }\end{array}$}} \\
\hline & & & & & & & \\
\hline \multicolumn{8}{|l|}{ Distal ulna } \\
\hline Proximal radius & & & & 1 & & & 1 \\
\hline Distal radius & & & & & & 1 & \\
\hline Carpal & & 1 & & & 1 & & 2 \\
\hline Proximal metacarpal & & & 1 & & 2 & 1 & 2 \\
\hline Distal metacarpal & & & 1 & 1 & 1 & & 2 \\
\hline \multicolumn{8}{|l|}{ Proximal femur } \\
\hline \multicolumn{8}{|l|}{ Distal femur } \\
\hline \multicolumn{8}{|l|}{ Proximal tibia } \\
\hline Distal tibia & 1 & & & 1 & 2 & 1 & 1 \\
\hline Small tarsal & & & & 1 & 5 & & \\
\hline Navicular-cuboid & & & & & & 2 & \\
\hline Astragalus & & & 1 & 2 & 1 & 1 & 1 \\
\hline Calcaneus & 1 & & & & 1 & & 2 \\
\hline Proximal metatarsal & 1 & 1 & & 2 & 2 & 3 & \\
\hline Distal metatarsal & & & 1 & & 1 & & 1 \\
\hline Distal metapodial & & & & 1 & & & 6 \\
\hline Phalanx 1 & 1 & 3 & 8 & 4 & 8 & 4 & 17 \\
\hline Phalanx 2 & 2 & & & 9 & 5 & 3 & \\
\hline Phalanx 3 & & & & & 2 & 2 & \\
\hline
\end{tabular}

sequence [Figure 5(a)-(b)]. The dominance of red deer in both the Late Glacial and Early post-Glacial faunal assemblages is a common pattern throughout the Mediterranean region of Europe (Gamble, 1986: 247). Bovids and asses [Figure 5(b)] are present in relatively constant, but small frequencies. Interestingly, the $12,000-10,000 \mathrm{BP}$ increase in the abundance of grasses suggested by the pollen (Figure 4) is not directly reflected by any similar increase in abundance of Equus against any other animal [Figure 5(b)]. This, however, may simply show that the resolution available to us is insufficiently fine for this level of comparison. The increase in pig abundance in the upper levels [Figure 5(a)] suggests an expansion of riverine-woodland habitat and corroborates the climatic explanation for the increase in roe deer frequency. 
Table 5. Body part frequency of Rupicapra/Capra remains from Badanj. Data are quantified as MNI. These data include all Rupicapra and Capra remains, as well as remains identified only as Rupicapra/Capra. Element categories as in Table 3

\begin{tabular}{|c|c|c|c|c|c|c|c|}
\hline \multirow[b]{2}{*}{ Body part } & \multicolumn{7}{|c|}{ Excavation levels } \\
\hline & $\begin{array}{l}1-2 \\
\text { MNI }\end{array}$ & $\begin{array}{l}2 \mathrm{AB} \\
\mathrm{MNI}\end{array}$ & $\stackrel{3}{\mathrm{MNI}}$ & $\stackrel{4}{\mathrm{MNI}}$ & $\stackrel{6}{\mathrm{MNI}}$ & $\begin{array}{c}8-10.14 \\
\text { MNI }\end{array}$ & $\begin{array}{c}13,16-17 \\
\text { MNI }\end{array}$ \\
\hline Horn core & & & I & & 2 & 1 & 1 \\
\hline Petrous & & & 2 & 2 & 1 & 1 & 2 \\
\hline Maxilla & 2 & 3 & 5 & 3 & 3 & 4 & 6 \\
\hline Mandible & 2 & 2 & 3 & 3 & 5 & 6 & 5 \\
\hline \multicolumn{8}{|l|}{ Atlas } \\
\hline Axis & & & & & & & 1 \\
\hline \multicolumn{8}{|l|}{ Cervical vertebra } \\
\hline \multicolumn{8}{|l|}{ Thoracic vertebra } \\
\hline \multicolumn{8}{|l|}{ Lumbar vertebra } \\
\hline \multicolumn{8}{|l|}{ Sacrum } \\
\hline Innominate & & & & & 1 & 1 & 2 \\
\hline \multicolumn{8}{|l|}{ Rib } \\
\hline \multicolumn{8}{|l|}{ Sternebra } \\
\hline Scapula & & & & & & 1 & 1 \\
\hline Proximal humerus & & & & & & & 1 \\
\hline Distal humerus & & & & & 1 & 1 & 2 \\
\hline Proximal ulna & & & & & 1 & 1 & 2 \\
\hline Distal ulna & I & & & & 1 & & \\
\hline Proximal radius & & & & 1 & & 2 & 1 \\
\hline Distal radius & & 1 & & & & 1 & \\
\hline Carpal & 1 & 1 & 1 & 1 & 3 & 4 & 4 \\
\hline Proximal metacarpal & & 2 & 2 & 1 & 1 & 3 & 2 \\
\hline Distal metacarpal & & & 1 & 1 & 1 & 2 & $i$ \\
\hline Proximal femur & & & & & & 1 & \\
\hline Distal femur & & & & & & & \\
\hline Proximal tibia & & & & & & & 1 \\
\hline Distal tibia & 1 & & & 2 & 1 & 3 & 2 \\
\hline Small tarsal & 3 & 1 & 5 & 2 & 2 & 1 & 7 \\
\hline Navicular-cuboid & 1 & I & 2 & 5 & 2 & 3 & 2 \\
\hline Astragalus & & & 1 & 2 & 2 & 3 & 4 \\
\hline Calcaneus & 1 & & 1 & 1 & 2 & 3 & 4 \\
\hline Proximal metatarsal & 1 & & 2 & 1 & 1 & 4 & 3 \\
\hline Distal metatarsal & & & 1 & i & $i$ & 2 & 3 \\
\hline Phalanx 1 & 1 & 1 & 2 & 1 & 2 & 2 & 3 \\
\hline Phalanx 2 & 1 & 1 & 1 & 2 & l & 2 & 2 \\
\hline Phalanx 3 & & 1 & 1 & 1 & 1 & 2 & 2 \\
\hline
\end{tabular}

Although there is a relatively steady abundance of red deer throughout the sequence, there is a very clear shift in the relative percentages of secondary animals, from chamois/ goats during the Late Glacial to roe deer during the Early post-Glacial [Figure 5(c)]. The surprise of the Badanj fauna is the abundance of chamois during the Late Glacial and its presence in all of the levels. The surprise is caused by our conception of chamois habitats, based on the present chamois distribution, namely, of high alpine in summer, and high coniferous woodland in winter. Neither environment exists today nor existed in the past around Badanj.

\section{The Local Geography of Badanj}

The site is located in the gorge of the Bregava River, a small, seasonally flowing tributary of the Neretva River (Figures 1 and 2). In the region of the site, the gorge averages $50 \mathrm{~m}$ in 
Table 6. Body part frequency of Capreolus remains from Badanj. Element categories as in Table 3

\begin{tabular}{|c|c|c|c|c|c|c|c|}
\hline \multirow[b]{2}{*}{ Body part } & \multicolumn{7}{|c|}{ Excavation levels } \\
\hline & $\begin{array}{c}1-2 \\
\text { MNI }\end{array}$ & $\begin{array}{l}2 \mathrm{AB} \\
\mathrm{MNI}\end{array}$ & $\stackrel{3}{\mathrm{MNI}}$ & $\stackrel{4}{\text { MNI }}$ & $\stackrel{6}{\mathrm{MNI}}$ & $\begin{array}{c}8-10,14 \\
\text { MNI }\end{array}$ & $\begin{array}{c}13,16-17 \\
\text { MNI }\end{array}$ \\
\hline \multicolumn{8}{|l|}{ Antler } \\
\hline Petrous & & 1 & & & & & \\
\hline Maxilla & 1 & 3 & & & 1 & 1 & \\
\hline Mandible & 2 & 4 & & & 1 & & \\
\hline \multicolumn{8}{|l|}{ Atlas } \\
\hline \multirow{2}{*}{\multicolumn{8}{|c|}{$\begin{array}{l}\text { Axis } \\
\text { Cervical vertebra }\end{array}$}} \\
\hline & & & & & & & \\
\hline \multicolumn{8}{|l|}{ Thoracic vertebra } \\
\hline \multicolumn{8}{|l|}{ Lumbar vertebra } \\
\hline \multicolumn{8}{|l|}{ Sacrum } \\
\hline Innominate & & 1 & & & & & \\
\hline \multicolumn{8}{|l|}{$\mathrm{Rib}$} \\
\hline \multicolumn{8}{|l|}{ Sternebra } \\
\hline Scapula & & 1 & & & & & \\
\hline $\begin{array}{l}\text { Scapula } \\
\text { Proximal humerus }\end{array}$ & & & & & & & \\
\hline \multicolumn{8}{|l|}{ Distal humerus } \\
\hline Proximal ulna & & 1 & & & & & \\
\hline \multicolumn{8}{|l|}{ Distal ulna } \\
\hline Proximal radius & 2 & 2 & & & & & \\
\hline \multicolumn{8}{|l|}{ Distal radius } \\
\hline Carpal & 1 & 1 & & & & & \\
\hline Proximal metacarpal & 3 & 2 & 1 & & & & \\
\hline Distal metacarpal & & 2 & 1 & & & & \\
\hline \multicolumn{8}{|l|}{ Proximal femur } \\
\hline \multicolumn{8}{|l|}{ Distal femur } \\
\hline Proximal tibia & 1 & & & & & & \\
\hline \multicolumn{8}{|l|}{ Distal tibia } \\
\hline \multicolumn{8}{|l|}{ Small tarsal } \\
\hline Navicular-cuboid & 1 & 1 & & & & & \\
\hline Astragalus & $i$ & & & & & & \\
\hline Calcaneus & 1 & 1 & 1 & & & & \\
\hline Proximal metatarsal & 1 & 3 & & & & & 1 \\
\hline Distal metatarsal & 1 & 1 & 1 & & & & \\
\hline Phalanx 1 & 1 & 1 & 1 & 1 & & & \\
\hline Phalanx 2 & 1 & 1 & 1 & & & & \\
\hline Phalanx 3 & $i$ & 1 & & & & & \\
\hline
\end{tabular}

depth. Access from the plateau to the bottom of the river valley, though restricted locally by cliffs, is possible at frequent intervals along the course of the gorge in which the site occurs. The river-valley setting of the site, though surely influenced by the desirability of a south-facing rockshelter, made riverine-woodland habitats available to its occupants. Northwest of the site, a wide area of plateau and rolling country forms a $10-20 \mathrm{~km}$-wide corridor between the coastal plain and the inland large depressions of the Nevesinjsko and Gatačko poljes (Figure 2). Much of this area is underlain by softer limestones and has a good soil cover. Older, apparently colluvial, accumulations of highly pedogenically altered terra rossa suggest that this soil environment prevailed in the past as well as today. Northeast of the site is the nearest $(9 \mathrm{~km})$ semi-mountainous area, Hrgud, with peaks at $1100 \mathrm{~m}$. The nearest truly mountainous areas are over $23 \mathrm{~km}$ north of the site. South of the 
Table 7. Body part frequency of Sus remains from Badanj. Element categories as in Table 3, with the exception of the navicular and cuboid, which are grouped with tarsals

\begin{tabular}{|c|c|c|c|c|c|c|c|}
\hline \multirow[b]{2}{*}{ Body part } & \multicolumn{7}{|c|}{ Excavation levels } \\
\hline & $\begin{array}{c}1-2 \\
\text { MNI }\end{array}$ & $\begin{array}{l}2 \mathrm{AB} \\
\mathrm{MNI}\end{array}$ & $\stackrel{3}{\mathrm{MNI}}$ & $\stackrel{4}{\mathrm{MNI}}$ & $\begin{array}{c}6 \\
\text { MNI }\end{array}$ & $\begin{array}{c}8-10,14 \\
\text { MNI }\end{array}$ & $\begin{array}{c}13,16-17 \\
\text { MNI }\end{array}$ \\
\hline \multicolumn{8}{|l|}{ Petrous } \\
\hline Maxilla & 1 & 2 & 1 & & 1 & 1 & 1 \\
\hline Mandibie & 1 & 2 & 1 & 1 & & 1 & \\
\hline \multicolumn{8}{|l|}{ Atlas } \\
\hline \multicolumn{8}{|l|}{ Axis } \\
\hline \multicolumn{8}{|l|}{ Cervical vertebra } \\
\hline \multicolumn{8}{|l|}{ Thoracic vertebra } \\
\hline \multicolumn{8}{|l|}{ Lumbar vertebra } \\
\hline \multicolumn{8}{|l|}{ Sacrum } \\
\hline \multicolumn{8}{|l|}{ Innominate } \\
\hline \multicolumn{8}{|l|}{ Rib } \\
\hline \multicolumn{8}{|l|}{ Sternebra } \\
\hline \multirow{2}{*}{\multicolumn{8}{|c|}{ Scapula }} \\
\hline \multicolumn{4}{|l|}{ Proximal humerus } & & & & \\
\hline Distal humerus & 1 & & & & & & \\
\hline \multicolumn{8}{|l|}{ Proximal ulna } \\
\hline \multicolumn{8}{|l|}{ Distal ulna } \\
\hline \multirow{2}{*}{\multicolumn{8}{|c|}{ Proximal radius }} \\
\hline & & & & & & & Distal radius \\
\hline Carpal & & 1 & 1 & & & & \\
\hline Proximal metacarpal & & 1 & & 1 & & & \\
\hline \multicolumn{8}{|l|}{ Distal metacarpal } \\
\hline \multicolumn{8}{|l|}{ Proximal femur } \\
\hline \multicolumn{8}{|l|}{ Distal femur } \\
\hline \multicolumn{8}{|l|}{ Proximal tibia } \\
\hline Distal tibia & & & & & & 1 & \\
\hline Tarsal & & & 1 & & & 1 & \\
\hline \multicolumn{8}{|l|}{ Astragalus } \\
\hline \multicolumn{8}{|l|}{ Calcaneus } \\
\hline Proximal metatarsal & & 1 & & & & & \\
\hline \multicolumn{8}{|l|}{ Distal metatarsal } \\
\hline Phalanx 1 & 1 & 1 & 1 & 1 & 1 & 1 & \\
\hline Phalanx 2 & 1 & 1 & 1 & & 1 & 1 & \\
\hline Phalanx 3 & 1 & 1 & & 1 & 1 & & \\
\hline
\end{tabular}

site, softer limestones are rare and the majority of the landscape today is "angry karst" with only small pockets of residual soil. While this is not a comprehensive list of variables of site location, it remains clear that Badanj is not strategically located for exploiting montane resources.

It is into this framework that we have attempted to place the major ungulate species found in the faunal remains from the site (Figure 6). We have attempted this for the early spring season, because of the relatively high frequency of fetal and neo-natal bones in the assemblages. We do not yet have the data to derive actual animal densities, but following the example of Sturdy \& Webley (1988) we have estimated the relative abundances of different animal species on our various terrain types. Bovids and equids would have been restricted to relatively gentle terrain. They cannot easily and safely negotiate the rougher terrain and "angry karst" and thus tend to avoid it. The red deer is a highly adaptable animal in terms of diet and temperature, and although it can negotiate a more rugged 
Table 8. Body part frequency of Bos/Bison remains from Badanj. Element categories as in Table 3

\begin{tabular}{|c|c|c|c|c|c|c|c|}
\hline \multirow[b]{2}{*}{ Body part } & \multicolumn{7}{|c|}{ Excavation levels } \\
\hline & $\begin{array}{c}1-2 \\
\text { MNI }\end{array}$ & $\begin{array}{l}2 \mathrm{AB} \\
\mathrm{MNI}\end{array}$ & $\stackrel{3}{\text { MNI }}$ & $\stackrel{4}{4}$ & $\stackrel{6}{\text { MNI }}$ & $\begin{array}{c}8-10,14 \\
\text { MNI }\end{array}$ & $\begin{array}{c}13,16-17 \\
\text { MNI }\end{array}$ \\
\hline \multicolumn{8}{|l|}{ Horn core } \\
\hline Maxilla & & & 1 & & 1 & & 1 \\
\hline Mandible & 1 & 1 & 1 & & & 1 & 1 \\
\hline \multicolumn{8}{|l|}{ Atlas } \\
\hline \multicolumn{8}{|l|}{ Axis } \\
\hline \multicolumn{8}{|l|}{ Cervical vertebra } \\
\hline \multicolumn{8}{|l|}{ Thoracic vertebra } \\
\hline \multicolumn{8}{|l|}{ Lumbar vertebra } \\
\hline \multicolumn{8}{|l|}{ Sacrum } \\
\hline \multicolumn{8}{|l|}{ Innominate } \\
\hline \multicolumn{8}{|l|}{ Rib } \\
\hline \multicolumn{8}{|l|}{ Sternebra } \\
\hline Scapula & & & 1 & & & & \\
\hline \multicolumn{8}{|l|}{ Proximal humerus } \\
\hline \multicolumn{8}{|l|}{ Distal humerus } \\
\hline \multicolumn{8}{|l|}{ Proximal ulna } \\
\hline \multicolumn{8}{|l|}{ Distal ulna } \\
\hline Proximal radius & & & & & 1 & & \\
\hline \multicolumn{8}{|l|}{ Distal radius } \\
\hline \multicolumn{8}{|l|}{ Carpal } \\
\hline \multirow{2}{*}{\multicolumn{8}{|c|}{$\begin{array}{l}\text { Proximal metacarpal } \\
\text { Distal metacarpal }\end{array}$}} \\
\hline & & & & & & & \\
\hline Proximal femur & & & & & & & 1 \\
\hline \multicolumn{8}{|l|}{ Distal femur } \\
\hline \multicolumn{8}{|l|}{ Proximal tibia } \\
\hline \multicolumn{8}{|l|}{ Distal tibia } \\
\hline Small tarsal & & 1 & & & & & \\
\hline Navicular-cuboid & & 1 & & & & & \\
\hline \multicolumn{8}{|l|}{ Astragalus } \\
\hline Calcaneus & & & & & & 1 & \\
\hline Proximal metatarsal & & & & 1 & & & \\
\hline \multicolumn{8}{|l|}{ Distal metatarsal } \\
\hline Phalanx 1 & 1 & 1 & & 1 & 1 & 1 & \\
\hline Phalanx 2 & 1 & & 1 & 1 & 1 & 1 & 1 \\
\hline Phalanx 3 & 1 & 1 & 1 & 1 & 1 & & \\
\hline
\end{tabular}

landscape than the Bos/Bison and equids, it is too large to handle the "angry karst". The goats are also adaptable in their use of the landscape. They can be placed wherever we can suggest suitable browse for them, especially on the rougher terrain where there is little competition from Bos/Bison, equids or deer. It is the chamois, however, which we find hard to place in the region around Badanj if we use the modern ecology of chamois as our guide.

Interpretation: Chamois and Karst

As pointed out in the discussion of the fauna, it is unlikely that chamois were brought in to the site from any considerable distance (say, $>5 \mathrm{~km}$ ). The chamois, therefore, have to be 
Table 9. Body part frequency of Equid remains from Badanj. Element categories as in Table 3, with the exception of the navicular and cuboid, which are grouped with tarsals

\begin{tabular}{|c|c|c|c|c|c|c|c|}
\hline \multirow[b]{2}{*}{ Body part } & \multicolumn{7}{|c|}{ Excavation levels } \\
\hline & $\begin{array}{c}1-2 \\
\mathrm{MNI}\end{array}$ & $\begin{array}{l}2 \mathrm{AB} \\
\mathrm{MNI}\end{array}$ & $\stackrel{3}{\mathrm{MNI}}$ & $\stackrel{4}{\mathrm{MNI}}$ & $\begin{array}{c}6 \\
\mathrm{MNI}\end{array}$ & $\begin{array}{c}8-10,14 \\
\mathrm{MNI}\end{array}$ & $\begin{array}{c}13,16-17 \\
M N I\end{array}$ \\
\hline \multicolumn{8}{|l|}{ Petrous } \\
\hline Maxilla & 1 & 1 & 1 & 1 & & 1 & 2 \\
\hline Mandible & 1 & 1 & 2 & 1 & 1 & $i$ & 1 \\
\hline \multicolumn{8}{|l|}{ Atlas } \\
\hline \multicolumn{8}{|l|}{ Axis } \\
\hline \multicolumn{8}{|l|}{ Cervical vertebra } \\
\hline \multicolumn{8}{|l|}{ Thoracic vertebra } \\
\hline \multicolumn{8}{|l|}{ Lumbar vertebra } \\
\hline \multicolumn{8}{|l|}{ Sacrum } \\
\hline Innominate & & & & & & & 1 \\
\hline \multicolumn{8}{|l|}{ Rib } \\
\hline \multicolumn{8}{|l|}{ Sternebra } \\
\hline \multicolumn{8}{|l|}{ Scapula } \\
\hline \multicolumn{8}{|l|}{ Proximal humerus } \\
\hline \multicolumn{8}{|l|}{ Distal humerus } \\
\hline \multicolumn{8}{|l|}{ Ulna } \\
\hline \multicolumn{8}{|l|}{ Proximal radius } \\
\hline Distal radius & & & & & & & 1 \\
\hline Carpal & 1 & & & & & & \\
\hline Proximal metacarpal & 1 & & 1 & & & & \\
\hline \multicolumn{8}{|l|}{ Distal metacarpal } \\
\hline \multicolumn{8}{|l|}{ Proximal femur } \\
\hline Distal femur & & & & & & 1 & \\
\hline \multicolumn{8}{|l|}{ Proximal tibia } \\
\hline Distal tibia & & & & 1 & & & \\
\hline Tarsal & 1 & 1 & & & 1 & & 1 \\
\hline \multicolumn{8}{|l|}{ Astragalus } \\
\hline \multicolumn{8}{|l|}{ Calcaneus } \\
\hline Proximal metatarsal & & & 1 & & & & \\
\hline \multicolumn{8}{|l|}{ Distal metatarsal } \\
\hline Phalanx 1 & 1 & 1 & 1 & 1 & 1 & & \\
\hline Phalanx 2 & 1 & & & & 1 & & \\
\hline Phalanx 3 & 1 & 1 & & 1 & 1 & & \\
\hline
\end{tabular}

placed in a plateau environment for at least part of the year. Modern chamois in alpine regions winter in higher parts of coniferous forests (Couturier, 1938; Corbet, 1966). While there is clear evidence of a steppe environment in Late Glacial Herzegovina, a possible expansion of coniferous forests does not appear to occur until the Early post-Glacial (Beug, 1967: 273) and this is exactly the time when the chamois decline in abundance. Therefore, there do not seem to be local habitats during the Late Glacial analogous to those of the modern chamois. Why were the chamois there?

The explanation that makes the most sense to us is that the chamois exploited the Late Glacial equivalent of the "angry karst". If we ignore the modern alpine distribution of the chamois and concentrate on its distinctive features, it is a very agile, neat-footed, small herbivore that can make effective use of vegetation in rugged terrain and harsh climate. Naturally, such an ability leaves it unchallenged in the high Alps today; we suggest that the same abilities made it ideally suited to exploit a colder version of "angry karst", which is, after all, only a horizontal version of a craggy environment. The skeletal morphology 

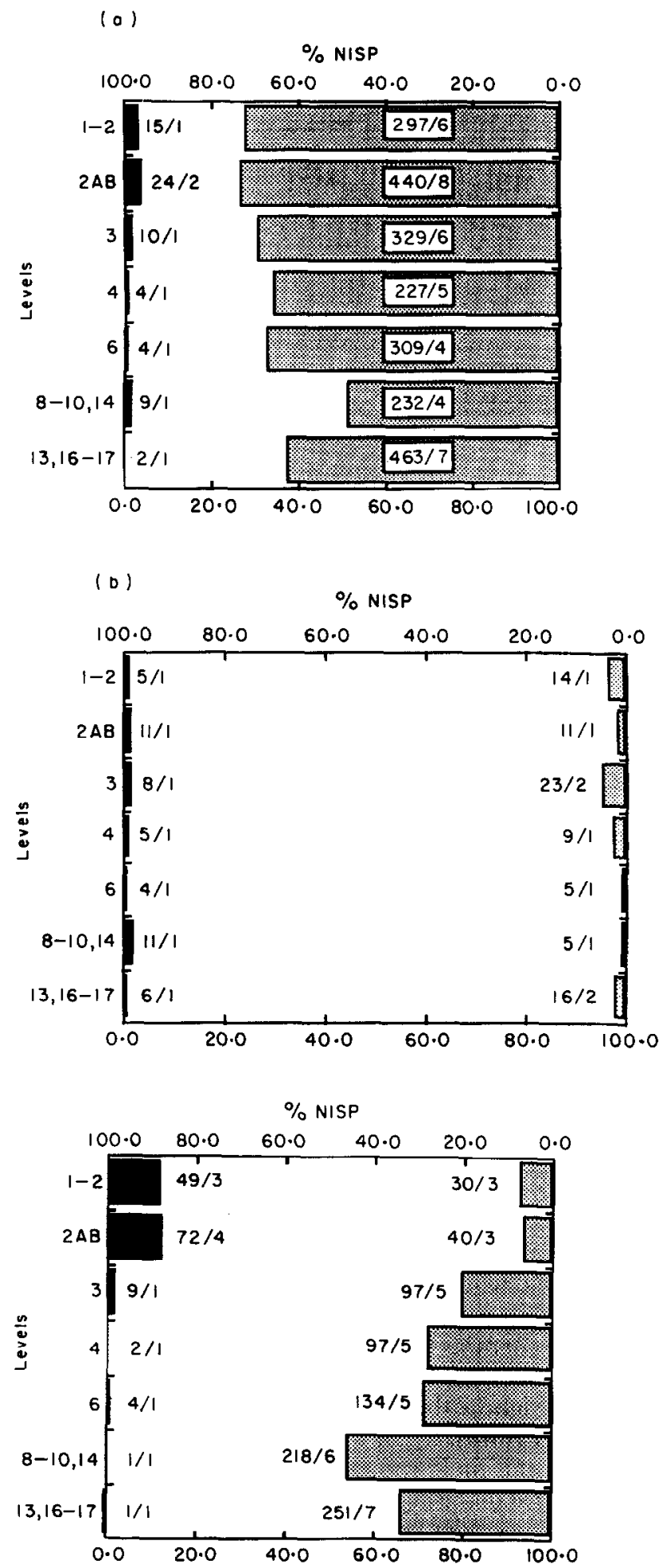

Figure 5. Faunal remains from Badanj. NISP/MNI totals are listed by excavation level for each species. (a) Cervus versus Sus; (b), Bos/Bison versus Equids; (c), Capreolus versus Rupicapra/Capra. (a) (口), Sus; (圆), Cervus; (b) (回), Bos/Bison; (圆), Equids; (c) (回), Capreolus; (国), Rupicapra/Capra. 


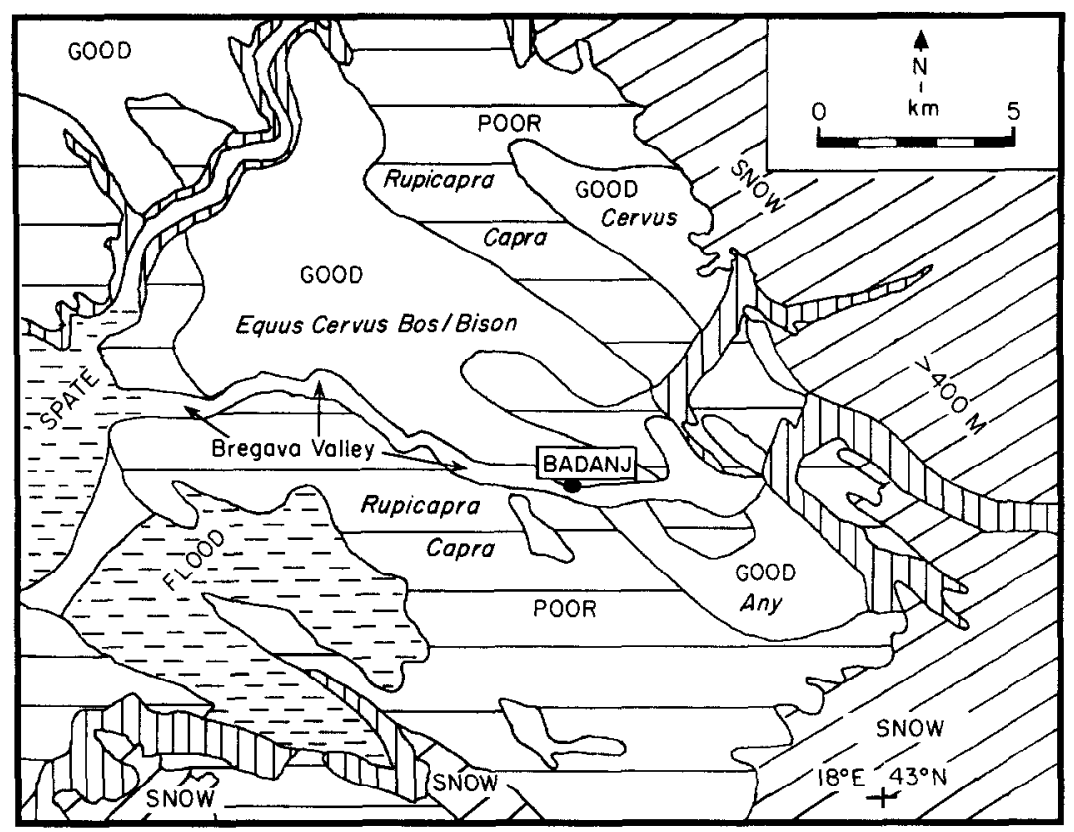

Figure 6. Reconstructed Late Glacial, Early Spring paleogeography around Badanj. ( $囚$ ), Land above early spring snow/frost line at $400-450 \mathrm{~m}$, adjusted for north/south aspect. (国), Areas likely to innundation by the start of spring thawing. (iii), Very steep river valleys or plateau edges. (), Poor grazing and browsing on plateau. Highly localized, thin or no soils on massive carbonate bedrocks, with spitzkarren-ridden surfaces. Inaccessible to bovids and equids, unattractive to Cervus. ( $\square$ ), Good grazing and browsing on plateau. Thicker silty soils on marly and chalky carbonate bedrocks without limb-breaking surface features such as spitzkarren. Attractive to bovids and equids because of easy access and better vegetation.

of chamois has not changed measurably between the Late Glacial and the present. The modest habitat change we are postulating is a function only of distribution, not morphology or diet.

The plateaus around Badanj, to satisfy this hypothesis, must have presented similar land surfaces in the Late Glacial as today. We noted above how the Early post-Glacial period saw an increase in soil cover on the "angry karst", and this is reflected by the replacement of chamois by roe deer in terms of relative abundance. When the soil and vegetational cover were reduced again, the chamois did not return as the exploiter of "angry karst"; its place, apparently, was taken by the modern domestic goat, whose smaller size compared to the Late Glacial $C$. ibex and association with humans gave it a competitive edge over the chamois. The increased temperatures of the Holocene compared to the Late Glacial were doubtlessly also important. In Herzegovina, therefore, the chamois' retreat to the highest available mountains may be a Holocene phenomenon (Kurtén, 1968: 175).

Although assemblages from Late Glacial, paleontological sites (Đurkovina II, Zelena Pećina, Zmijinac Pećina) in the area do not contain chamois (Table 10) all of those assemblages appear to represent either cave bear lairs ( Durkovina II, Zmijinac Pećina) or sink hole traps (Zelena Pećina, Zmijinac Pećina). If chamois are adapted to a "sure-footed niche", then one would expect them to be less likely to fall into the ubiquitous sink holes of 
Table 10. Paleontological assemblages in Southern Herzegovina and Croatia

\begin{tabular}{|c|c|c|c|c|}
\hline \multirow{2}{*}{$\begin{array}{l}\text { Site } \\
\text { Date } \\
\text { References } \\
\text { Mammalian taxa }\end{array}$} & \multicolumn{2}{|c|}{$\begin{array}{c}\text { Durkovina II } \\
16,781 \pm 394(\mathrm{Z}-331) \\
\text { Malez }(1987 a, b) \\
\text { Malez et al. }(1979)\end{array}$} & \multirow{2}{*}{$\begin{array}{c}\begin{array}{c}\text { Zelena Pécina } \\
27,376 \pm 1365(Z-391) \\
\text { Malez }(1980), \\
\text { Malez et al. }(1979)\end{array} \\
\text { NISP }\end{array}$} & \multirow{2}{*}{$\begin{array}{c}\begin{array}{c}\text { Zmijinac Pećina } \\
19,399 \pm 470(\mathrm{Z}-322) \\
\text { Malez }(1981) \\
\text { Malez et al. }(1979)\end{array} \\
\text { NISP }\end{array}$} \\
\hline & NISP & MNI & & \\
\hline Ursus speleaus & Many & 23 & & + \\
\hline Ursus artos & 4 & 1 & & \\
\hline Capra ibex & 2 & 1 & + & \\
\hline Cervus elaphus & & & & + \\
\hline Megaceros giganteus & & & & + \\
\hline Sus scrofa & & & & + \\
\hline Capreolus capreolus & & & & + \\
\hline Canis lupus & & & & + \\
\hline Vulpes vulpes & & & & + \\
\hline Sorex alpinus & & & + & \\
\hline Lepus timidus & & & + & + \\
\hline Castor fiher & & & & + \\
\hline Marmota marmota & & & + & \\
\hline Microtus nivalis & & & + & \\
\hline
\end{tabular}

the karst of Herzegovina. Additionally, the presence of chamois in assemblages from Crvena Stijena, the nearest contemporary of Badanj, suggests that chamois were locally present in the environment (Benac, 1957; Benac \& Brodar, 1958; Malez, 1967).

In summary, the Badanj fauna, when considered at the coarse level of resolution used here, is in many ways typical of Late Glacial and Early post-Glacial faunal assemblages in Mediterranean Europe. Its distinctive character, however, lies in the relative Late Glacial abundance of chamois in a non-montane environment. Vegetational change does not appear to have been the immediate cause of a decline in chamois; a more complicated interaction of climate, vegetation, and later changes in the Capra populations under human influence, is needed to explain the Holocene history of the chamois.

A corollary of our argument is that, if the chamois is indicative of "angry karst" in Late Glacial Herzegovina as proposed, then the Mid Holocene "degradation" of the Herzegovinan karst areas may reflect a return to the more normal Pleistocene condition of the karst. The deeper soils and extended tree cover of the Early Holocene may be the unusual case, at least in the time window of the Late Pleistocene. This inverts the common conception of a fragile landscape as subject to one-way degradation. If we increase the time scale at which we consider the karst landscape to include the Late Glacial, we might conclude that the typical "overgrazing" hypothesis for explaining karst "degradation" is misleading because the time scale it uses is too short. White (1988: 355$)$, for example, has written that "a grim monument to the effects of overgrazing can be seen in the barren limestone mountains of the countries around the Mediterranean. Out-of-control goat populations, beginning as early as biblical times, stripped trees, bushes and grasslands". If, in fact, goat and chamois were characteristic of a treeless Late Glacial karst, then this "fall-from-The-Garden-of-Eden" view may need to be modified. The "degraded" landscape of today, and that which we postulate for the Late Glacial in Herzegovina, may have been the normal Late Pleistocene landscape, while a period of soil accumulation and tree cover was the unusual result of peculiar, short-lived (2-4 ky) conditions during the Early Holocene. Similar arguments could apply to other areas of the northern Mediterranean, 
where some semi-arid limestone landscapes may have had thin, patchy soil covers and exposed, rugged karstic land surfaces during the Late Glacial as at present, and the chamois could have been more widely spread to exploit them.

\section{Conclusion}

The Herzegovinan chamois had a much wider distribution in the Late Glacial than it has at present. Its presence in the lowland plateaus around Badanj is, in our view, a function of the existence of a landscape, a Late Glacial version of the modern "angry karst", that it was well suited to exploit, but which other animals would have found too hostile. We can caution against the rigid application of modern chamois habitats in interpreting past environments elsewhere. Indeed, we are seeking to interpret Pleistocene ungulate ecology in terms of first principles rather than applying direct analogues from the present. In this way one can begin to use the past to understand the present instead of repeating the fallacy of imposing the present on the past. We also suggest that the widespread view of the Late Holocene degradation of the Herzegovinan karst should be viewed in a wider time window, where the exceptional circumstance is not the modern landscape of "angry karst", but the short (2-4 ky) period in the Early Holocene when the landscape was not so desolate.

\section{Acknowledgements}

We particularly wish to thank Charles Turner for his assistance with vegetational history data. Geoff Bailey and Robert Whallon generously gave advice and assistance at all stages of research. We also thank William Farrand, Richard Klein, Lawrence Straus and an anonymous reviewer for their useful comments and suggestions. Only we are to blame, however, for any mistakes that remain. The radiocarbon dates were graciously supplied by the Oxford University Radiocarbon Accelerator Unit. Field research was largely supported by a grant from the International Programmes division of the National Science Foundation to the University of Michigan Museum of Anthropology and the Zemaljski Muzej, Sarajevo, Bosnia-Herzegovina.

\section{References}

Bartolomei, G., Broglio, A. \& Palma di Cesnola, A. (1979). Chronostratigraphie et écologie de l'Epigravettien en Italie. In (D. de Sonneville-Bordes, Ed.) La Fin des Temps Glaciaires en Europe. Paris: Colloques Internationaux du CNRS, No. 271, pp. 297-324.

Benac, A. (1957). Crvena Stijena, 1955 (I-IV stratum). Glasnik Zemaljskog Muzeja 12, 19-50.

Benac, A. \& Brodar, M. (1958). Crvena Stijena, 1956. Glasnik Zemaljskog Muzeja 13, 21-64.

Beug, H. J. (1962). Uber die ersten anthropogene Vegetationsveranderungen in Suddalmatien an Hand eines neuen Pollendiagrammes vom "Malo Jezero" auf Mljet. Veröffentlichung Geobotanischen Institutes Rubel in Zurich 37, 9-15.

Beug, H. J. (1967). On the forest history of the Dalmatian coast. Revue Paléobotanique et Palynologique 2, 271-279.

Beug, H. J. (1975). Man as a factor in the vegetational history of the Balkan Peninsula. In Problems of Balkan Flora and Vegetation: Proceedings of the First International Symposium on Balkan Flora and Vegetation, Varna, June 7-14, 1973. Sofia, pp. 72-77.

Binford, I. R. (1978). Nunamiut Ethnoarchaeology. New York: Academic Press.

Bonifay, M. F. (1982). Paléoclimatologie quantitative: méthode fondée sur les grands mammifères quaternaires et première application aux régions sud de la France. Palaeogeography, Palaeoclimatology, Palaeoecology 38, 207-226.

Bottema, S. (1974). Late Quaternary Vegetation History of Northwestern Greece. Gronigen: University Press.

Bouchud, J. (1975). Étude de la faune de l'Abri Pataud. In (H. L. Movius, Ed.) Excavation of the Abri Pataud, les Eyzies (Dordogne). Harvard: American School of Prehistoric Research, Peabody Museum, Harvard University, Bulletin 30, pp. 69-153. 
Brande, A. (1973). Untersuchungen zur postglazialen Vegetationsgeshichte im Gebiet der Neretva-Niederungen (Dalmatien, Herzegowina). Flora 162, 1-44.

Corbet, G. B. (1966). The Terrestrial Mammals of Western Europe. Philadelphia: Dufour.

Couturier, M. A. J. (1938). Le Chamois. Grenoble: Arthaud.

Cvijić, J. (1960). La Géographie des Terrains Calcaires. Monographs of the Serbian Academy of Science and Arts 341.

Gamble, C. S. (1986). The Palaeolithic Settlement of Europe. Cambridge: Cambridge University Press.

Herak, M. (1972). Karst of Yugoslavia. In (M. Herak \& V. T. Stringfield, Ed.) Karst: Important Karst Regions of the Northern Hemisphere. Amsterdam: Elsevier, pp. 25-83.

Huntley, B. \& Birks, H. J. B. (1983). Atlas of Past and Present Pollen Maps. Cambridge: Cambridge University Press.

Kurtén, B. (1968). Pleistocene Mammals of Europe. London: Weidenfeld \& Nicolson.

Malez, M. (1967). Gornjopleistocenska fauna Crvene Stijene. (Upper Pleistocene fauna from Crvena Stijena, with German summary). Glasnik Zemaljskog Muzeja 31/32, 67-79.

Malez, M. (1980). Speleokronološki odnosi u nekim spiljama Bosne i Hercegovine (Speleological chronology in some caves in Bosnia and Herzegovina, in Serbo-Croation and English). Naš Kr ̌̌ 6, 3-32.

Malez, M. (1981). Fosilni vertebrati na podrućju Biokova (Fossil vertebrates in the region of Biokova, with German summary). Acta Biokovica 1, 39-70.

Malez, M. (1987a). Pleistocenski sisavci (Mammalia) iz spilje Durkovine (Hercegovina, Jugoslavija). (Pleistocene mammals from Durkovine cave, with English abstract and German summary). RAD Jugoslavenske Akademije Znanosti i Umjetnosti 431, 93-130.

Malez, M. (1987b). Spiljski medvjed (Ursus spelaeus Rosenm. \& Heinroth) iz Pećine-Durkovine u Hercegovini. (Cave bear from Durkovina cave in Herzegovina). Geološki Glasnik, Sarajevo 30, 71-111.

Malez, M., Sliepčević, A. \& Srdoč, D. (1979). Određivanje starosti metodom radioaktivnog ugljika kvartarnim naslagama na nekim lokalitetima u Dinarskom kršu. (Radiocarbon analyses of Quaternary deposits from some localities in the Dinaric karst, with English abstract and German summary). RAD Jugoslavenske Akademije Znanosti i Umjetnosti 383, 227-271.

Rodić, D. P. (1986). Geografija Jugoslavije II (The Geography of Yugoslavia II). Beograd: Naučna Knjiga.

Sturdy, D. A. \& Webley, D. P. (1988). Palaeolithic geography; or where are the deer? World Archaeology 19, 262-280.

van Andel, T. H. \& Sutton, S. B. (1987). Landscape and People of the Franchthi Region. In (T. W. Jacobsen, Ed.) Excavations at Franchthi Cave, Greece, Fascicle 2. Bloomington: Indiana University Press.

Whallon, R. (1989). The Paleolithic site of Badanj: recent excavations and results of analysis. Glasnik Zemaljskog Muzeja 44, 7-20.

White, W. B. (1988). Geomorphology and Hydrology of Karst Terrains. Oxford: Oxford University Press. 